\title{
COMPETITION, TOTAL QUALITY MANAGEMENT PRACTICES, AND PERFORMANCE: EVIDENCE FROM UPSCALE HOTELS
}

\author{
ANOOP PATIAR, $*$ MICHAEL C. G. DAVIDSON, $\uparrow$ and YING WANG $\dagger$ \\ *Department of Tourism, Leisure, Hotel and Sport Management, Nathan Campus, \\ Griffith University, QLD, Australia \\ $\dagger$ Department of Tourism, Leisure, Hotel and Sport Management, Gold Coast Campus, \\ Griffith University, QLD, Australia
}

\begin{abstract}
Hotels operate in a highly competitive market and therefore place a strong emphasis on quality management in order to gain/maintain competitiveness. This research examined the relationship between total quality management (TQM), market competition, and hotel departmental financial and nonfinancial performance. The data were collected from a sample of Australian and Indian hotels using a self-administered postal survey. The results suggested that while TQM and market competition had a direct interactive effect on hotel departmental nonfinancial performance, the effect on the financial performance was indirect. It was also suggested that those hotels subscribing to TQM philosophy were more likely to thrive on competition.
\end{abstract}

Key words: Total quality management (TQM); Market competition; Departmental performance; Hotels

\section{Introduction}

The hospitality industry has experienced continuous expansion over the last three decades to become one of the world's largest industries in terms of creating employment and assisting in earning invisible exports (Leiper, 2003). At the same time, competition in this industry has become increasingly intensified (Ingram \& Daskalakis, 1999; Kandampully \& Suhartanto, 2000). The way in which hotels gain a competitive edge falls into two main categories: price based, by establishing a low-cost leadership through discounting; and quality based, by providing customers with a unique experience to achieve customer loyalty. Although the former helps increase a hotel's market share in the short term, it may negatively impact on profitability in the long term (Kandampully \& Suhartanto, 2000). Many hotels therefore have turned to quality improvement for achieving a competitive advantage (Ingram \& Daskalakis, 1999).

In recent decades three main approaches to quality management have been the focus of research and application. The ISO 9000 standard introduced 
by the International Standards Organization in 1987 focuses on business processes rather than outcomes. The ISO 9000 quality standard has not been popular, particularly among hotels, because it requires formal procedures to be developed for the implementation and control of all aspects of business operations (Ingram \& Daskalakis, 1999). In the UK, the BS 5750 is an alternative to ISO 9000 with some hotel subscriptions (Callan, 1992). SERVQUAL is perhaps the most popular approach used for measuring service quality and has been developed from the expectancy disconfirmation theory. SERVQUAL views service quality as the outcome of customer comparison between expectations and perceived service in five dimensions: tangibles, reliability, responsiveness, assurance, and empathy. It helps identify sources of quality deficiency, and subsequent strategies for quality improvement (Parasuraman, Zeithaml, \& Berry, 1985; Zeithaml, Parasuraman, \& Berry, 1990). However, understanding customer expectations has been shown to be problematic; customers either do not know what they want or do not give a clear indication of what they want (Lim \& Tang, 2000).

Another group of studies has focused on the application of total quality management (TQM). This approach emphasizes not only the quality management system itself as in ISO 9000, but also includes supporting systems such as strategic planning systems, information systems, and operational systems. The relevance of such a holistic approach is apparent for hotels, because hotel patrons judge service quality of accommodation and food and beverage outlets as an overall experience, rather than the aggregation of individual service elements (Wilkins, Merrilees, \& Herington, 2007). While TQM has received increasing emphasis in research studies in a general management context, little has been applied to the tourism and hospitality industry, and in particular, to the hotel sector.

The hotel industry is distinctly different from other service sectors (e.g., banks and retail shops). Particularly at the upper end of the hotel industry, which has much broader international footprint than other services sectors, major hotel brands and subbrands own properties in locations throughout both the developed and developing countries. Even under the same brand/subbrand, there are several types of operation with differentiated staffing characteristics (i.e., remote island resorts and business hotels in metropolitan areas). The use of management contracts is extensive in this industry, resulting in the separation of ownership from management and operation, which is not commonly seen in other service sectors. Additionally, the hotel industry has features of both a manufacturing and a service industry, with the production and consumption processes taking place simultaneously on the same premises. The unique characteristics of the hotel industry imply a high level of sophistication in the operation that may impact on business processes and quality management (Yu, 2008). A study dedicated to the hotel industry is therefore warranted.

TQM's impact on organizational performance has been investigated vigorously in a broad context but to a much less extent in the hospitality industry. Empirical findings generally support the proposition that TQM leads to overall performance improvement (i.e., Aarts \& Vos, 2001; Feng, Prajogo, Tan, \& Sohal, 2006; Harrington \& Akehurst, 1996; Nield \& Kozak, 1999; SantosVijande \& Álvarez-González, 2007; Sit, Ooi, Lin, $\&$ Chong, 2009). However, there is no clear conclusion with regard to whether TQM has direct profit implications (Kaynak, 2003). Literature also suggests that TQM interacts with organizational characteristics and environmental factors to jointly affect organizational/departmental performance. Nevertheless, there is a lack of empirical examination in this regard (Nair, 2006). Hence, a number of gaps such as knowledge of TQM's application and its relevance to the hotel sector need to be addressed.

The first gap was revealed in our literature search that limited studies examined the drivers of performance in hotels. For instance, Patiar and Mia (2008a) found that nonfinancial performance improved when managers perceived high intensity of competition and made an extensive use of management accounting systems (MAS) information. Similarly, Patiar and Mia (2009) reported that as managers were empowered, particularly working under transformational leaders, they made greater use of MAS information resulting in optimized nonfinancial performance. To enrich the hospitality literature and assist practicing managers, other drivers of performance such as TQM (a comprehensive set of management techniques, see more 
details under Literature Review) should also be examined. Secondly, the research effort on TQM in service sectors has not matched the increasing importance of these sectors - in particular the tourism and hospitality industry — and as Wilkins et al. (2007) noted, there is limited research on service quality in hotels. Thirdly, studies in hospitality and tourism sectors have focused on individual dimensions of TQM, mainly the human resource management aspect (Sila \& Ebrahimpour, 2002). However, service quality is a holistic concept that demands a holistic total service quality approach (Wilkins et al., 2007). Fourthly, empirical findings of the TQM and performance links are not conclusive, calling for more research to investigate the impact of TQM on organizational performance (Kaynak, 2003; Sila \& Ebrahimpour, 2002). Finally, there is a lack of empirical findings related to examining the effects of environmental and organizational factors on the effectiveness of TQM (Chong \& Rundus, 2004; Hendricks \& Singhal, 2001; Nair, 2006; SantosVijande \& Álvarez-González, 2007; Sila \& Ebrahimpour, 2002; Zeithaml, 2000).

To address the identified gaps and in particular extend Patiar and Mia's (2008a, 2009) works, more studies are needed to reveal how market competition exerts its influence. This study aims to investigate the relationships between TQM, market competition, and departmental performance in large four- and five-star hotels in Australia and India. By proposing and testing an interaction effect of TQM and market competition on hotels departments' comprehensive performance, it extends TQM knowledge in a hospitality context and attempts to fill the existing knowledge gaps as discussed above.

This article is divided into the following sections. A review of literature on the relationships between TQM, market competition, and comprehensive performance is presented, leading to the development of two research hypotheses. After detailing the research methods and data analysis procedure, the results and their implications for the hotel industry are discussed. The article concludes with a discussion of the series of findings and the directions for future research.

\section{Literature Review}

The hotel sector began focusing on the concerns for product and service quality management in the 1980s for both internal and external reasons. Internally, hotels wanted to reduce costs and defects to improve effectiveness and efficiency, and to make quality culture a focal point for management (Claver, Tarí, \& Pereira, 2006). Externally, hotels faced increased competition and ever more demanding consumers. It was perceived that quality management programs could help enhance hotel corporate image and enable them to adapt to market needs, and to attract new customers (Chacko, Davidson, \& Green, 2005). In other words, the impact of quality management on hotels' performance was seen as improving internal processes and applying aggressive marketing techniques (Claver et al., 2006). In addition to the various approaches to quality management, TQM has been shown to provide a basis for a sustainable business (Flynn, Schroeder, \& Sakakibara, 1994).

\section{Total Quality Management}

Although there are variations in the constituent components of TQM, the Malcolm Baldrige National Quality Award (MBNQA), originating in the US, has been used by many as the best research framework for an interdisciplinary approach (i.e., Curkovic, Melnyk, Calantone, \& Handfield, 2000; Kuo, Chang, Hung, \& Lin, 2009; Wilson \& Collier, 2000). MBNQA sees TQM as a comprehensive amalgamation of several quality management practices and outcomes: leadership; information and analysis; strategic quality planning; human resource development and management; management of process quality; customer focus and satisfaction; and quality and operational results (Rao et al., 1996). These components are used collectively to stimulate quality improvement and support the continuous development of organizational capability, which together, gives an organization competitive advantage (Flynn et al., 1994).

Founded on the MBNQA, the European Foundation for Quality Management (EFQM) developed another holistic quality management framework that has nine criteria divided into enablers (leadership, people management, policy and strategy, partnerships and resource, processes) and results (people results, customer results, society results, and key performance results). With many parallels with the MBNQA, the EFQM model also focuses 
on total quality and accentuates organizational excellence and continuous improvement (Nabitz, Klazinga, \& Walburg, 2000). A number of other studies aimed at developing reliable measurement of quality management constructs, for instance, Saraph, Benson, and Schroeder (1989), Flynn et al. (1994), and Flynn and Saladin (2001, 2006).

Hotels have increasingly embraced TQM as a way to gain competitiveness. For instance, the RitzCarlton Hotel Chain adopted TQM practice and has achieved exceptional customer service, winning the MBNQA twice in the recent years. TQM has helped the hotel group to achieve exceptional customer service (Wylie, 2009). According to Claver et al. (2006), hotels that developed quality management systems to create and maintain a quality image in the market, start on the right pathway to Total Quality (TQ) and improve service quality. However, there is evidence of limited research on TQM in the hospitality and tourism industry (Sila \& Ebrahimpour, 2002). Researchers have also questioned the genuineness of TQM application in hotels, claiming that some hotels were paying only lip service. It was sometimes more ritualistic and hypocritical than practical and genuine (Baldacchino, 1995), and failed to take a holistic approach (Harrington \& Akehurst, 1996).

Overall, TQM provides positive benefits in terms of reduced cost, increased market share, and improved profitability to organizations. It has been found useful in both small and large companies, and in both service- and manufacturing-oriented companies (Rao et al., 1996). Its effectiveness, however, varies to different degrees depending on organizational characteristics. For instance, the effectiveness of TQM programs was found to be strongly linked to organizational structure (Tata, Prasad, \& Thorn, 1999) and Arasli (2002) found that four-star hotels were more successful than five-star hotels in transitioning to TQM policies and implementations. Tarí, Claver-Cortés, PereiraMoliner, and Molina-Azoín (2010) also suggested a significant association between organizational characteristics and hotels' commitment to quality management. Hotels having a higher star rating, more rooms, more facilities, a higher room rate, and chain affiliation to a greater extent were found to be more proactive in quality management.
In addition, there are a range of impediments such as fear of losing management prerogatives at supervisory level and a range of structural factors (i.e., turnover, job insecurity, distrust towards management fuelled by job insecurity and industrial conflict) that were found to have negatively influenced effective TQM practices. According to Baldacchino (1995), Day (1994), Rao et al. (1996), and Sila and Ebrahimpour (2002), lack of leadership, narrowly focused training, no long-term organizational commitment, lack of customer focus, and the use of generic TQM models have a negative impact on the successful implementation of quality initiatives.

\section{TQM and Departmental Performance}

TQM is deployed by organizations for its ability to enable better performance, a multiple-faceted construct that has been measured by financial performance (i.e., market share, sales per employee, return on assets, and return on capital), operational performance (i.e., errors, cost savings, timeliness of delivery), product quality, customer service and satisfaction (i.e., overall satisfaction, customer complaints, customer retention), and employee relations (i.e., extent of workforce participation) (Nair, 2006; Rao et al., 1996). Dimensions of performance may be grouped into two categories: financial and nonfinancial. The former reflects managers' ability to operate under resource and budget capacity, and the latter indicates their ability to manage staff and customer satisfaction (Patiar \& Mia, 2008a, 2009). Researchers have agreed that subjective nonfinancial performance should not be interpreted as a convenient substitute for financial performance (Harris, 2001). Instead, an effective performance measurement system should incorporate suitable financial and nonfinancial indicators (Patiar \& Mia, 2008a).

TQM may impact on financial performance either directly or indirectly. The direct link is established through cost reduction resulting from quality improvement, while the indirect link is established through better customer satisfaction and subsequently improved financial performance (Rust, Zahorik, \& Keiningham, 1995). Prior research that analyzed the direct relationship between TQM and 
organizational financial performance has shown mixed results (i.e., see Kaynak, 2003 for a review of studies on the TQM-performance link). Although some studies (Buzzell \& Gale, 1987, cited in Harrington \& Akehurst, 1996; Chow-Chua, Goh, \& Wan, 2003; Rust et al., 1995) noted a positive relationship between quality management and financial return, others (i.e., Aaker \& Jacobson, 1994; Aarts \& Vos, 2001; Wilson \& Collier, 2000; see Zeithaml, 2000 for more studies) failed to verify such a proposition.

Among the above mentioned studies, Rust et al. (1995) found that investment on effort of quality improvement generated a healthy return of $44 \%$ over a period of 3 years. Buzzell and Gale (1987, cited in Harrington \& Akehurst, 1996) revealed a positive relationship between perceived quality and profitability. However, the majority of organizations included in their study were situated in the manufacturing industries. It is not clear whether the results are applicable to services sectors. A study by Powell (1995) implied that, although managers in the manufacturing industry reported higher satisfaction with their TQM programs than firms in the services sector, they did not enjoy greater financial performance. On the other hand, Aaker and Jacobson (1994) claimed that expenditure on quality management does not have obvious profit implications. Aarts and Vos (2001) further added that ISO-registered organizations performed below average in the capital market. In a hotel service quality context, Harrington and Akehurst (1996) found hotels that subscribed to service quality philosophy did not seem to have outperformed those that did not in either financial or competitive terms. Likewise, Walker and Salameh (1990) reported that quality management in hotels had the greatest positive effect on employee satisfaction, but its effect on profit margins was not significant.

The mixed picture painted by these studies may be attributable to the fact that implementing a quality management system entails additional resources, at least in the short term. These resources are both monetary and nonmonetary, such as the cost of obtaining a quality certification, the time used in implementing quality systems, a greater operational bureaucracy, and employee development (Ingram \& Daskalakis, 1999; Nield \& Kozak,
1999). Expenditure on improvement is also associated with a diminishing return on investment. It can help improve profitability to a certain point, but past that point, further investment is unprofitable (Rust et al., 1995). Additionally, although quality improvements are often expected to result in lower costs, this is more likely to be observed in manufacturing fields and the more standardized services such as the fast food industry. Highly service-oriented businesses like luxury hotels are less likely to benefit as customization of services toward a sophisticated market prevents economies of scale making quality practice less cost-effective in those organizations (Rust et al., 1995).

As for its influence on nonfinancial performance, in service-oriented organizations, quality management results in improved customer service, which offers organizations two benefits: a higher customer retention rate, because existing customers are highly satisfied and are inclined to come back, and an ability to attract new customers through word of mouth and the opportunities to reposition themselves by advertising quality of service (Ekinci, 2008; Rust et al., 1995). These benefits have been validated in many tourism and hospitality studies that found significant links between service quality/satisfaction and behavioral intention (i.e., Kandampully \& Suhartanto, 2000; Zeithaml, Berry, \& Parasuraman, 1996). These benefits and a possible cost reduction jointly contribute to greater profitability.

The ability of quality management to influence nonfinancial performance has been empirically tested. Feng et al. (2006) and Santos-Vijande and Álvarez-González (2007) both found that TQM enabled organizations to have a greater capacity for innovation. Wilson and Collier (2000) reported that although top management commitment to TQM was not directly related to financial and customer satisfaction performance, it drove system performance, hence influenced overall performance indirectly through an improved business process.

Studies conducted in a service or hospitality context have generally supported the link between quality management and nonfinancial performance. In Malaysia's services sector, Sit et al. (2009) found that TQM dimensions of leadership, customer focus, information and analysis, and human 
resource focus had a positive association with customer satisfaction. Quality management practices were found to produce tangible benefits for hospitality organizations through an improved operating system (Nield \& Kozak, 1999) and resulted in remarkable improvement in service quality and customer satisfaction, decreased costs and increased sales, and competitive position (Claver et al., 2006). They also found that quality management's impact on financial performance was the least obvious among all performance dimensions. Similarly, the study by Claver-Cortés, Pereira-Moliner, Tarí, and Molina-Azoín (2008) on Spanish hotels showed positive influence of TQM on competitive performance and stakeholder satisfaction, but no such influence on financial performance. More importantly, Nair (2006) conducted a meta-analysis on studies focusing on the relationship between quality management practices and organizational performance, and reaffirmed the positive role of quality management in overall performance improvement.

As previously discussed, TQM's nonfinancial benefits combined with cost reduction may lead to an improved financial performance. Based on the above discussion, it is logical to assume that in a hotel context, TQM may have a positive and direct impact on hotel financial performance as well as an indirect impact on financial performance existing through nonfinancial performance.

\section{TQM, Market Competition, and Performance}

Market competition is "essentially strife in the market place" (Khandwalla, 1972, p. 276); it may be measured in three aspects: the intensity of price competition, the intensity of competition in promotion, as well as the intensity of competition in product and service quality (Khandwalla, 1972; Patiar \& Mia, 2008a). As one of the key situational factors in the external operating environment, market competition prompts organizations to adopt TQM practices so managers could deal with threats and challenges presented by their competitors (Chong \& Rundus, 2004) and achieve better control of cost, production, marketing, and finance (Khandwalla, 1972).

Indeed, in the competitive environment, hotel businesses that have robust quality products and services are more likely to find themselves in a stronger position to attract potential customers to repeatedly buy their products and services than those that have poor quality products and services. Moreover, in the competitive environment, managers have pressure to effectively manage their costs as hotels are labor intensive businesses. TQM implementation can assist in achieving the cost saving objective. If managers perceive low intensity of market competition, they would sell their products and services with little effort. Therefore, it is argued in this article that when managers perceive uncertainty in the work environment (i.e., intense market competition also gives rise to considerable uncertainty), they will need to embrace more innovative systems and ideas for their businesses survival (Chong \& Eggleton, 2003; Chong \& Rundus, 2004; Gul \& Chia, 1994; Mia \& Clarke, 1999; Simons, 1990).

TQM's relationship with market orientation is explicitly shown by its emphasis on customer satisfaction. As defined by Schonberger (1992), TQM is "a set of concepts and tools for getting all employees focused on continuous improvement, in the eyes of the customer-the next process as well as the final consumer" (p. 17). The increased competition that hotels are facing results in a stronger focus on customer needs and product design in a bid to gain competitive advantages through enhancing customer satisfaction (Banker, Lee, Potter, \& Srinivasan, 1996).

For long-term survival, a competitive organization must be able to accurately understand the environment it is operating in, to satisfy market needs, and to continuously adapt to new market rules (Santos-Vijande \& Álvarez-González, 2007). This requires the organization to have a superior market sensing capacity that determines its ability to sense and respond to changes in the market, and customer linking capacity that refers to the skills, abilities, and processes in place to achieve collaborative customer relationships and to respond to customer needs. TQM offers a rich array of tools that emphasize an individual's empowerment and management to achieve incremental but continuous improvement in business processes. It also provides guidance on the design of an effective change program to build these capacities and enables the organization to become market oriented (Day, 1994). Since the quality standard an organization adopts is benchmarked by that 
of its competitors (Chong \& Rundus, 2004), the organization's decision to improve quality through TQM is influenced by its competitors and the intensity of market competition.

A number of studies have attempted to examine how market competition and TQM interact with each other to impact on organizational performance. Chong and Rundus (2004) found that TQM practices in general were not significantly related to nonfinancial organizational performance, but they had significant impact on organizations operating in a highly competitive environment, and "the higher the degree of market competition, the more positive the relationship between the TQM practices of customer focus and organizational performance" (p. 155). This implies a two-way interaction (combined effect) between TQM and market competition to impact on an organization's nonfinancial performance. Santos-Vijande and Álvarez-González (2007) asserted that TQM assists in creating an organizational culture that is receptive to innovation and its impact on innovation varies considerably under different levels of market competition. Under stronger market competition, TQM exerts a direct effect on technical innovation that is not the case within the more stable markets. Similarly, Das, Handfield, Calantone, and Ghosh (2000) found international competition to impact on the relationship between quality management and customer satisfaction performance.

Focusing on the hotel sector, Patiar and Mia (2008a) extended the investigation to the hotel industry and found that the extent of market competition and departmental financial performance are negatively related implying that being profitable is more difficult in a highly competitive environment. The study also revealed a combined effect of market competition and the use of management accounting systems (MAS), which reflects a hotel's practice in the information and analysis dimension of quality management, on nonfinancial performance of departments; however, there was no such effect on the financial performance. The authors attributed this to a lack of control of cost and an ability to generate revenue independently at the departmental level. The above studies focused on single dimensions of TQM. It has also been noted that there has been a limited effort to investigate the link between the intensity of market competition and TQM practices in hotels (Patiar \& Mia, 2008a).

In summary, to achieve optimal performance, an organization must align with its environment where the intensity of market competition is an important component that affects the deployment and effectiveness of quality management practices. Likewise, the use of TQM also affects an organization's ability to respond to competition.

It is therefore logical to assume an interaction effect of TQM and market competition on performance. Hence, two hypotheses have been developed to test this effect.

H1: There is an interaction effect of TQM and the intensity of market competition on hotel departmental financial performance.

$\mathrm{H} 2$ : There is an interaction effect of TQM and the intensity of market competition on hotel departmental nonfinancial performance.

\section{Research Methods}

To collect data, a questionnaire was administered to a sample of hotels in Australia and India. Large four- and five-star hotels and resorts with more than 140 bedrooms were chosen as the research subjects as these hotels are more likely to have a departmental management structure. Research suggests that such large luxury hotels and resorts are in a stronger position to adopt TQM, a process that requires special knowledge, skill, and substantial investment in time, cost, and other resources (Arasli, 2002). The study focused on departmental performance and senior managers of the two major profit centers (i.e., in term of size, number of employees, and budget): Food and Beverage Department and Room Division were targeted in the survey. This is supported by Patiar and Mia (2009), who argue that hotels and resorts operating departments, namely food and beverage departments and room departments, are the key contributor of hotels' sales revenue and the major source of employment. Moreover, Food and Beverage and Room Department managers are an integral part of a hotel's executive management team, and have complete responsibility of effectively managing the operations and the operating budgets. Ethics approval for the study was obtained from the University Ethics Committee in 2008. 
In recognition that top management interest in the research is critical to secure a desirable response rate, data collection followed a two-stage procedure. Initial contact was made with 285 four- and five-star hotels and resorts in Australia (165) and India (120) identified from the hotel guides. Telephone calls to each general manager were made to explain the purpose of the research and to seek permission to allow their Food and Beverage and Room Department managers to participate in the study. Following the telephone contact with the general managers' office, 90 hotels in Australia and 75 hotels in India confirmed willingness to participate in the study. A questionnaire package was mailed to only those hotels.

The questionnaire was based on the relevant literature and appraised for reliability prior to hypothesis testing. The questionnaire included sections of multiple-item Likert scale measurements of TQM practices, market competition, and departmental performance, as well as demographic details of managers and hotels. To improve its relevance and reliability, the questionnaire was pilot tested on three department managers from four- and five-star hotels and on three hospitality management academics. Managers who participated in the pilot test were excluded from the final sample.

The package contained a questionnaire for each Food and Beverage and Room Department manager, a prepaid return envelope, and an information sheet outlining the research objectives, explaining the importance of the study and ensuring confidentiality. Each respondent was asked to assess their respective departmental performance, use of TQM practices, and the perceived intensity of market competition.

A usable response was received from a total of 57 hotels (114 department managers) in Australia and a total of 30 hotels (59 department managers) in India. This provided an overall response rate of $30 \%$ (Australia 34.5\% and India 25\%, respectively). Consistent with Oppenheim (1996) and Wallace and Mellor's (1988) approach to establish nonresponse bias of returned questionnaires received after the first and the second mailing, a $t$-test was performed to determine if there was a significant difference between the responses received through the first and second mailings. The results indicated that there were no significant difference in the mean scores of TQM, competition, and department performances. Accordingly, both sets of first and second questionnaires were combined and used to analyze the data.

\section{TQM Practices}

Department managers' use of TQM was measured on a multi-item Likert-type scale adapted from Flynn et al. (1994) and Flynn and Saladin (2001, 2006). Following the MBNQA framework, these studies identified key TQM constructs and developed measurement scales based on extensive literature reviews and empirical testing of reliability and validity. The prime reason for adapting Flynn et al. (1994) and Flynn and Saladin (2001, 2006) instrument in this study was due to its practical relevance to the hotel operations (i.e., food and beverage and rooms) resembling manufacturing as well as services processes. The final TQM scale contained six subscales that measure various dimensions of TQM in hotels, including leadership behaviors, people management, identification of customer needs, planning and control dimensions, information and analysis, and process management. Managers were asked to rate the extent of their usage of various TQM practices on 5-point scales ranging from 1 "sometimes" to 5 "always." For example, "in my hotel everyone's involvement is encouraged to provide quality products and services."

A literature search uncovered that the use of multiple dimensions of TQM (Das et al., 2000; Feng et al., 2006; Jun, Cai, \& Shin, 2006; Nilsson, Johnson, \& Gustafsson, 2001; Wilson \& Collier, 2000) as well as a single dimension to examine its effect on performance (Douglas \& Judge, 2001; Easton \& Jarrell, 1998; Kaynak, 2003; Powel, 1995; Sila, 2007). Consistent with the approach of Douglas and Judge (2001), Easton and Jarrell (1998), Kaynak (2003), Powel (1995), and Sila (2007), mean of the items was taken to represent the extent of TQM practice in hotels. Cronbach alpha of 0.96 for TQM is comparable with other researchers results and suggest the instrument is reliable (Nunnally, 1978). See Table 2 for the descriptive statistics and the reliability scores.

\section{Performance}

Departmental performance was measured on an eight-item scale adapted from Gupta and 
Govindarajan (1984). The scale was validated by Patiar and Mia (2008a, 2009). The eight items were related to operational innovation, revenue increase, rooms occupancy/food and beverage outlets occupancy levels, average room rate/average customer spending in food and beverage outlets, repeat business, staff training and development, staff morale, and operating budget. Respondents were asked to rate how satisfied they had been with their department's performance on 5-point Likert-type scales from 1 "not at all satisfactory" to 5 "highly satisfactory." A factor analysis extracted two factors, with financial indicators grouped in one factor and nonfinancial indicators in the other, and explaining $59.2 \%$ of the total variance. The Cronbach's alpha test statistics for the two factors were 0.80 and 0.76 , respectively, indicating that the measurements were reliable (Nunnally, 1978). The factor means were used in hypothesis testing for financial and nonfinancial performances. See Table 2 for the descriptive statistics and the reliability scores.

While some literature criticizes the use of subjective performance measurement on the basis of its soft measures and managers' self-reporting of performance owing to the leniency bias. There is an extant literature that advocates no notable empirical differences between objective and subjective measures of performance (Covin, 1991; Dess \& Robinson, 1984) as well as between senior managers' evaluation of their subordinates' performance and subordinates' self-reporting of their performance (Heneman, 1974; Patiar \& Mia, 2008b; Venkatraman \& Ramnujan, 1987). Hence, consistent with the published literature, the decision was made to use the subjective measures of performance and the self-reporting of performance evaluation (Gul, 1991; Gul, Tsui, Fong, \& Kwok, 1995; Jogaratnam, Tse, \& Olsen, 1999; Patiar \& Mia, 2008b; Tsui, 2001).

\section{Market Competition}

Market competition was measured by a threeitem scale adapted from Khandawalla (1972) and validated by Patiar and Mia (2008a, 2009) where intensity of market competition was reflected in three aspects: price, product, and promotion. Respondents were asked to indicate how difficult it had been for them to manage market competition in terms of products and services charged by their competitors, the quality of competitor products and services, and the marketing efforts of the competitors. A factor analysis extracted a single-factor solution, explaining $67.8 \%$ of the total variance and with a Cronbach alpha coefficient of 0.74 , indicating the reliability of this construct (Nunnally, 1978). Responses were measured on 5-point scales with 1 being "not difficult at all" to 5 "extremely difficult." Market competition was calculated as the mean of the three items. See Table 2 for the descriptive statistics and the reliability scores.

\section{Research Model and Testing Procedure}

As mentioned earlier, the means of the measurements for TQM, market competition, and financial and nonfinancial performances were computed to be used in hypothesis testing. In this study, hypotheses involving hotel managers' perception of market competition and their use of TQM practice were formulated to assess the two-way interaction effect on hotel departments' financial and nonfinancial performances. The following multiple regression equations were used to test the hypotheses.

$$
\begin{aligned}
& Y_{i}=\beta_{0}+\beta_{1} C+\beta_{2} Q+\beta_{3} C Q+\varepsilon \\
& Y_{i i}=\beta_{0}+\beta_{1} C+\beta_{2} Q+\beta_{3} C Q+\varepsilon
\end{aligned}
$$

where $C=$ competition, $Q=$ TQM practice, $Y_{\mathrm{i}}=$ financial performance; $Y_{\mathrm{ii}}=$ nonfinancial performance, $C Q=$ competition and TQM practice interaction, and $\varepsilon=$ error term.

As can be seen in the two equations, this study adopted a multiplicative form of interactive effect and the interaction variables were constructed by multiplying the scores of TQM and market competition. Responses to the questionnaires were analyzed using the SPSS 17 statistical package and the results are detailed in the following section.

\section{Results}

\section{Descriptive Statistics}

The sample comprises the Food and Beverage Department managers and Room Department managers of the participating hotels and resorts, and their characteristics are reported in Table 1. The respondents are predominantly young to middle-aged 
Table 1

Characteristics of the Respondents $(n=173)$ and Hotels $(n=87)$

\begin{tabular}{lrr}
\hline Variables & $n$ & $\%$ \\
\hline Gender & & \\
Male & 126 & 72.8 \\
Female & 47 & 27.2 \\
Age & & \\
21-30 years & 44 & 25.4 \\
31-40 years & 94 & 54.3 \\
41-49 years & 29 & 16.8 \\
50 or over years & 6 & 3.5 \\
Country of department managers (hotels) & & \\
Australia & $114(57)$ & 65.9 \\
India & $59(30)$ & 34.1 \\
Highest qualification & & \\
School certificate & 26 & 15.0 \\
Hospitality diploma & 59 & 34.1 \\
Bachelor degree & 57 & 32.9 \\
Master degree & 25 & 14.5 \\
Other qualifications & 6 & 3.5 \\
Professional experience & & \\
1 year or more & 6 & 3.5 \\
2-3 years & 28 & 16.2 \\
4-6 year & 26 & 15.0 \\
7-9 years & 41 & 23.7 \\
10 or more years & 72 & 41.6 \\
Hotel rating & & \\
Four stars & 48 & 55.2 \\
Five stars & 39 & 44.8 \\
\hline & & \\
\hline & &
\end{tabular}

males with tertiary qualifications. More than half of the respondents had a professional career in hotels of more than 7 years. The sample is skewed towards Australia with two out of three respondents working in an Australian hotel. The respondent managers working in four- and five-star hotels and resorts are reasonably well distributed.

Hypotheses were tested using multiple regression analysis described earlier. Table 2 summarizes the descriptive statistics and correlation matrix for all dependent and independent variables in the estimation models.

\section{Hypothesis Testing}

H1 proposes an interaction effect of TQM and market competition on hotel departmental financial performance. Table 3 reports the estimation results for equation 1 (financial performance) and equation 2 (nonfinancial performance). $\mathrm{H} 1$ and $\mathrm{H} 2$ were tested by examining the sign and significance of the coefficient of the interaction effect terms $\beta_{3}$ in the two equations. Furthermore, various environmental, institutional, and demographic factors may impact on the relationship between dependent and independent variables in regression modeling and their effects must be controlled in order to focus on the interaction effect between market competition and TQM. Tolerance and VIF test values suggested that multicollinearity was present and centering the variables is often recommended as a remedy for this problem in interactive regression models (i.e., Aiken, West, \& Reno, 1991; Kleinbaum, Kupper, \& Muller, 2008; Tabachnick \& Fidell, 2007). Model estimation thus used centered dependent and independent variables that were created by subtracting each variable by its mean. Equation 1 with controlled variables of department managers' gender, age, qualifications, job identification, country identification, professional experience, as well as star rating, was estimated and presented in Table 3.

Table 3 (financial performance for equation 1) shows that, although the estimated model is significant (adjusted $R^{2}=18.9 \%, F$-value $=5.00, p<$ 0.01 ), the coefficient $\beta_{3}$ is not significant. Therefore, there is no evidence to support $\mathrm{H} 1$ that such an interaction effect exists to directly affect financial performance.

$\mathrm{H} 2$ proposes an interaction effect of TQM and market competition on hotel departmental nonfinancial performance. As can be seen in Table 3 for equation 2 (nonfinancial performance), the overall

Table 2

Mean, SD, Reliability Alpha, and Correlations $(n=173)$

\begin{tabular}{lccccccccr}
\hline Variables & Mean & Mini & Maxi & SD & $\alpha$ & 1 & 2 & 3 & 4 \\
\hline 1. TQM & 4.09 & 2.17 & 5 & 0.52 & 0.96 & 1 & & & \\
2. Market competition & 3.32 & 1.67 & 5 & 0.66 & 0.76 & $0.27 * *$ & 1 & & \\
3. Financial performance & 3.91 & 2.40 & 5 & 0.59 & 0.80 & $0.41^{* *}$ & 0.09 & 1 & \\
4. Nonfinancial performance & 3.82 & 2.25 & 5 & 0.61 & 0.78 & $0.42^{* *}$ & 0.06 & $0.57^{* *}$ & 1 \\
\hline
\end{tabular}

${ }^{*} p<0.05,{ }^{* *} p<0.01$. 
Table 3

Relationship of TQM, Market Competition, Performance, and Controlled Variables $(n=173)$

\begin{tabular}{|c|c|c|c|c|c|c|c|}
\hline \multirow[b]{2}{*}{ Variables } & \multirow[b]{2}{*}{ Coefficient } & \multicolumn{3}{|c|}{ Financial Performance } & \multicolumn{3}{|c|}{ Nonfinancial Performance } \\
\hline & & B & SEB & $\beta$ & $\mathrm{B}$ & SEB & $\beta$ \\
\hline Constant & $\beta_{0}$ & 0.17 & 0.31 & & 0.36 & 0.32 & \\
\hline TQM (Q) & $\beta$ & 0.43 & 0.08 & $0.38 * *$ & 0.54 & 0.09 & $0.46 * *$ \\
\hline Market competition (C) & $\beta_{2}$ & 0.01 & 0.07 & 0.01 & -0.03 & 0.07 & -0.04 \\
\hline $\mathrm{Q} \times \mathrm{C}$ & $\beta_{3}^{2}$ & 0.04 & 0.11 & 0.03 & 0.37 & 0.11 & $0.24^{* *}$ \\
\hline Gender & $\beta_{4}^{3}$ & -0.02 & 0.10 & -0.01 & 0.03 & 0.10 & 0.02 \\
\hline Age & $\beta_{5}^{4}$ & -0.12 & 0.06 & -0.15 & -0.05 & 0.06 & -0.06 \\
\hline Qualification & $\beta_{6}^{3}$ & 0.04 & 0.04 & 0.07 & 0.01 & 0.04 & 0.01 \\
\hline Country ID & $\mathrm{B}_{7}$ & 0.20 & 0.09 & $0.16^{*}$ & -0.01 & 0.10 & -0.01 \\
\hline Professional experience & $\mathrm{B}_{8}^{\prime}$ & 0.07 & 0.04 & 0.14 & 0.03 & 0.04 & 0.07 \\
\hline Star rating & $\mathrm{B}_{0}^{8}$ & -0.08 & 0.07 & -0.09 & -0.11 & 0.07 & -0.11 \\
\hline Managers job ID & $\mathrm{B}_{1}$ & -0.07 & 0.08 & -0.06 & -0.02 & 0.09 & -0.01 \\
\hline & & $23.6 \%$ & & & $24.8 \%$ & & \\
\hline Adjusted $R^{2}$ & & $18.9 \%$ & & & $20.2 \%$ & & \\
\hline$F$-value & & $5.00 * *$ & & & $5.36^{* *}$ & & \\
\hline
\end{tabular}

${ }^{*} p<0.05, * * p<0.01$.

model is significant with an adjusted $R^{2}$ of $20.2 \%$ and an $F$-value of $5.36(p<0.01)$. The coefficient $\beta_{3}$ is positive and significant $(p<0.01)$, suggesting a significant interaction effect of market competition and TQM practices on hotel departmental nonfinancial performance. $\mathrm{H} 2$ is therefore supported. It is argued that when the researcher's interest is in observing the interaction term, it is not necessary to interpret other variables in the model (Govindarajan, 1986; Southwood, 1978). Moreover, it is clear that various control variables did not affect the interaction effect of market competition and TQM given the nonsignificant coefficients.

According to Schoonhoven (1981), the reporting of the two-way interaction ought to be supplemented with establishing the nature and the form of the interaction relationship. A further insight into the relationship between hotel department managers' perception of market competition and their use of TQM practice on nonfinancial performance is provided by determining the partial derivative of the TQM practice as shown in equation 3 .

$$
\delta Y / \delta C=\beta_{1}+\beta_{3} Q
$$

The unstandardized coefficient values for TQM practice $\left(\beta_{1}\right)$ and the interaction of TQM practice and market competition $\left(\beta_{3}\right)$ from Table 3 (nonfinancial performance) are substituted in equation 3 .

$$
\delta Y / \delta C=0.54+0.37 Q
$$

From the results presented in Figure 1, graphically it is evident that the relationship between nonfinancial performance and market competition is negative, when the practice of TQM is low or less than 1.46 (i.e., $0.54 / 0.37$, the inflection point). Moreover, the relationship between nonfinancial performance and market competition is positive when the practice of TQM is more than 1.46. In other words, department managers' perception of the intensity of market competition impedes their department's nonfinancial performance if they do not

Nonfinancial performance

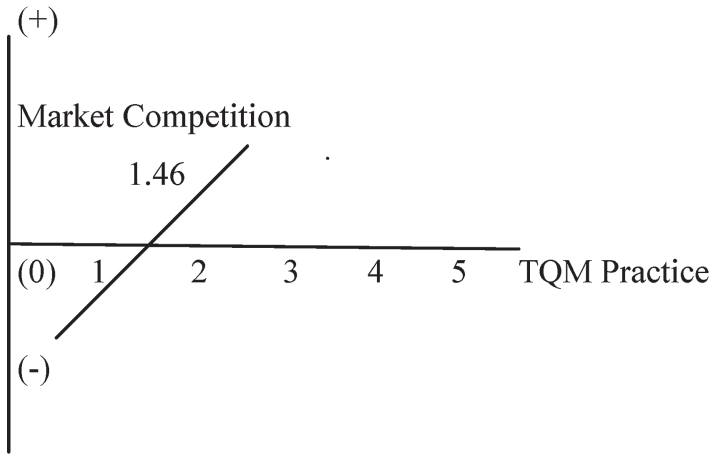

Figure 1. Interaction of market competition and TQM practice on hotel departmental nonfinancial performance. 
embrace TQM practice in managing their respective operations (i.e., Food and Beverage, and Rooms).

\section{Discussion}

A department's performance can be affected by a wide range of environmental and organizational factors. Focusing on hotels, this research investigated the impact of two such factors: the use of TQM and the intensity of market competition, on performance at departmental level.

Theoretically, TQM may impact on financial performance directly and indirectly (Rust et al., 1995). Nevertheless, empirical findings in this regard have generated mixed results. The coefficient of the two-way interaction effect of TQM and market competition on financial performance is not significant, demonstrating no support for $\mathrm{H} 1$.

Supporting H2, a department's nonfinancial performance was found to be determined jointly by the manager's use of TQM and his/her perception of the intensity of market competition. Chong and Rundus (2004), Patiar and Mia (2008a) and SantosVijande and Álvarez-González (2007) revealed that TQM practices impacted on firm performance to a varied degree under different levels of market competition. These studies were conducted either outside the tourism and hospitality industry, or with a focus on a single dimension of TQM. In line with these studies, the present study extends the findings to TQM application in hotels and concludes that hotels are more likely to benefit from a holistic quality management program in a competitive market. It was also suggested that as a department manager adapts to TQM practices, the existing relationship between market competition and departmental performance may change.

The results presented in Figure 1 revealed the nonmonotonic nature of this relationship. In departments where the manager used TQM favorably, the relationship between nonfinancial performance and competitive intensity was positive; however, this relationship was negative in departments where TQM practices were less favorably used. This finding may offer another explanation for the nonsignificant results reported in some studies regarding the TQM-performance and market-performance links. As suggested by this study, TQM and market competition do not exercise their influence on nonfinancial performance independently but interactively. The findings in relation to $\mathrm{H} 1$ and $\mathrm{H} 2$ collectively imply an indirect interactive impact of TQM and market competition on financial performance existing through nonfinancial performance. For instance, researchers (i.e., Banker, Potter, \& Srinivasan, 2005; Kaplan \& Norton, 1992; Kaynak, 2003; Patiar \& Mia, 2009; Rust et al., 1995; Sila, 2007) have argued that nonfinancial performance drives financial performance.

Consistent with previous researchers we also found support for the proposition, implying that those departments performing well in nonfinancial performance indicators are likely to experience improved financial outcomes measured in terms of revenue and customer spending, and in meeting the operating budget. This finding is expected as the nonfinancial performance indicators such as overall customer satisfaction, repeat business, and employee morale are generally regarded as antecedents of profitability. This is because greater satisfaction is associated with higher retention rate, which in turn can positively affect profitability (Zeithaml, 2000). Furthermore, there is a general belief that satisfied customers are willing to pay higher prices, which subsequently increases revenue and profit. Empirical evidence obtained primarily outside of the hospitality industry suggests that those firms achieving high customer satisfaction also enjoy high profitability through enhanced customer loyalty or positive word of mouth (e.g., Anderson, Fornell, \& Lehmann, 1994; Anderson, Fornell, \& Rust, 1997; Chi \& Gursoy, 2009; Helgesen, 2006; Reichheld \& Sasser Jr., 1990). The same can be applied to hotels that are able to produce premier quality in their products and services.

Evidence of the interactive effect of TQM and market competition, and of the link between nonfinancial and financial performance is important. This is because it provides justification for investing in quality improvement and market-oriented activities by clarifying the roles that TQM and market play in contributing to greater customer satisfaction, leading in the longer term, to greater financial performance. Hotels are profit-oriented businesses in which any expenditure is considered an investment. Budget and resource constraints require hotels to direct scarce financial and human resources towards the more profitable elements. 
Rust et al. (1995) asserted that expenditure on quality management would be considered discretionary, if it does not generate sufficient return on investment.

When the competition is low under conditions such as a very strong demand or monopoly/oligopoly market, hotels may be able to stay profitable without investing heavily on market-oriented activities and quality improvement (i.e., Au \& Tse, 1995). However, most hotels, particularly those in urban areas, operate under monopolistic competition, a common market structure with features of competitive and monopoly markets. The competitive market feature refers to a large number of hotels in the same geographic area engaging in intense and dynamic competition, while its monopoly element features competition based on differentiated products with the intention of making the demand less elastic to gain more control over price (Tribe, 2005). Strong market/customer orientation is vital in such a situation, and hotels need to be competitive and at the same time meet customer expectation. If a hotel can consistently deliver differentiated and not easily duplicated quality experiences, a positive relationship with its customers can be created and maintained.

It is argued that quality is a moving target as customer expectation may increase in association with intensified competition and marketing activities (Chacko et al., 2005; Knox, 2007). This dynamic nature of service quality creates the need for continuous improvement, which in turn, requires TQM to be implemented in hotels. Without a doubt managers must recognize TQM as an integrated quality improvement philosophy that encompasses all areas of business and considers not only the external customers but also internal customers: the employees. The MBNQAP introduced earlier provides a useful starting point from which to implement TQM practices in hotels.

\section{Conclusion and Implications}

This study was undertaken to examine the relationships between TQM, market competition, and departmental performance in hotels. The findings are useful to both practitioners and academics who are interested in the consequences of developing a TQM philosophy and a culture of market orientation within hotels and the broader tourism and hospitality industry. The study concluded that, first, there is a direct interaction effect of TQM and market competition on nonfinancial departmental performance; second, there is no such an effect on financial departmental performance; and third, there may be an indirect interaction effect of TQM and market competition on financial performance existing through financial performance. These findings have theoretical and practical implications.

The findings of this study extend previous studies and contribute to fill a number of knowledge gaps identified in literature. Existing studies (Sila \& Ebrahimpour, 2002; Wilkins et al., 2007) have acknowledged a lack of research on the application of TQM in a tourism and hospitality context as well as a need to move from individual dimensions of TQM to TQM as a whole. Responding to these needs, this study is concerned with TQM overall rather than its individual dimensions; it also extends the limited research on TQM and market competition to the hotel industry. By recognizing the external effects on the effectiveness of TQM practice and organizational performance as well as investigating the combined effect of TQM and market competition on hotel departments' ability to perform. This study also makes a contribution to enhance our understanding of how environmental and organizational factors interact with quality practices, an area on which little research has been conducted (Chong \& Rundus, 2004; Hendricks \& Singhal, 2001; Nair, 2006; Patiar \& Mia, 2008a; Santos-Vijande \& Álvarez-González, 2007). Additionally, this study addresses Banker et al.'s (2005) call for more investigations of the relationship between different measures of performance. It distinguishes financial performance from nonfinancial performance and provides empirical support for the proposition that superior performance in nonfinancial measures can lead to financial success.

There are also practical implications associated with the research findings. First, the findings encourage the use of TQM within hotels by suggesting that hotels subscribing to TQM philosophy would be in a better position to thrive on competition. Second, the findings also demonstrate to hotel managers that their investment in quality management can be paid back. However, a long-term commitment to TQM practices is needed because the 
return on TQM investment might not be reflected immediately in hotels' financial statement. Rather, it is achieved through an improved nonfinancial performance in a competitive market. Third, programs must be established to build hotels' market sensing and customer linking capacity. Such programs should regularly monitor the status of market competition and more importantly, keep managers informed of the intensity of competition that the department is facing so as to maintain a continuous state of awareness and responsiveness to any changes in the market. Forth, in light of the result that the interactive effect of TQM and market competition did not vary across different control variables, it seems that there is little need for tailored implementation of TQM programs based on departments and star ratings.

\section{Limitations and Future Research Direction}

It is worth noting that this research has limitations that point to a number of directions for further research. First, the analysis was based on the subjective interpretation of performance by management, a common problem in measuring performance (Harris, 2001) and service quality research (Zeithaml, 2000). Future studies should consider the use of objective measures of performance (e.g., return on assets, return on investment, and Tobin's Q) and include the superior's evaluation of their subordinates' performance. As service quality is a customer perceived concept, future studies should benefit from measuring customer perceived quality or using a combined measure incorporating both management data and customer data. Second, this study focuses on TQM as one construct without differentiating the effects of various dimensions of TQM and their relative importance in driving performance. Further research could go beyond the scope of this study to investigate the effect of individual dimensions of TQM and to map how TQM dimensions interact with each other as well as with market competition to affect performance. Research in this regard will help hotel managers understand what aspects of TQM are most vital in impacting on performance, thereby aiding decision making on resource allocation. Third, this study did not include time as a control variable and future studies ought to assess the long-term effect of TQM implementation using a longitudinal study approach. Additional organizational characteristics should also be included as control variables. Additionally, performance was measured at the departmental level where, although a reasonable amount of autonomy exists, management is still heavily influenced by top managers (i.e., general manager). This restricts the applicability of results to the organizational level. In future, this study can be extended to include other departments or entire hotels. Finally, future studies can also consider the effect of TQM on human resources outcomes (e.g., employee turnover rate, employee absenteeism, and employee job performance), operational effectiveness, and consumer results demonstrated by customer retention and perceived value for money.

\section{References}

Aaker, D. A., \& Jacobson, R. (1994). The financial information content of perceived quality. Journal of Marketing Research, 31(2), 191-201.

Aarts, F. M., \& Vos, E. (2001). The impact of ISO registration on New Zealand firms' performance: A financial perspective. The TQM Magazine, 13(3), 180-191.

Aiken, L. S., West, S. G., \& Reno, R. R. (1991). Multiple regression: Testing and interpreting interactions. Thousand Oaks, CA: Sage Publications.

Anderson, E. W., Fornell, C., \& Lehmann, D. R. (1994). Customer satisfaction, market share, and profitability: Findings from Sweden. Journal of Marketing, 58(3), 53-66.

Anderson, E. W., Fornell, C., \& Rust, R. T. (1997). Customer satisfaction, productivity, and profitability: Differences between goods and services. Marketing Science, 16(2), $129-145$.

Arasli, H. (2002). Diagnosing whether northern Cyprus hotels are ready for TQM: An empirical analysis. Total Quality Management, 13(3), 347-364.

$\mathrm{Au}$, A. K. M., \& Tse, A. C. B. (1995). The effect of marketing orientation on company performance in the service sector: A comparative study of the hotel industry in Hong Kong and New Zealand. Journal of International Consumer Marketing, 8(2), 77-87.

Baldacchino, G. (1995). Total quality management in a luxury hotel: A critique of practice. International Journal of Hospitality Management, 14(1), 67-78.

Banker, R. D., Lee, S-Y., Potter, G., \& Srinivasan, D. (1996). Contextual analysis of performance impacts of outcome-based incentive compensation. Academy of Management Journal, 39(4), 920-948.

Banker, R. D., Potter, G., \& Srinivasan, D. (2005). Association of nonfinancial performance measures with the financial performance of a lodging chain. Cornell Hotel and Restaurant Administration Quarterly, 46(4), 394-412. 
Callan, R. J. (1992). Quality control at Avant hotels - the debut of BS 5750. The Service Industries Journal, 12(1), $17-33$.

Chacko, H., Davidson, M. C. G., \& Green, Y. (2005). The "big easy or the hard ask": A case study of service quality in New Orleans hotels. Journal of Hospitality and Leisure Marketing, 13(3/4), 183-205.

Chi, C G., \& Gursoy, D. (2009). Employee satisfaction, customer satisfaction, and financial performance: An empirical examination. International Journal of Hospitality Management, 28(2), 245-253.

Chong, V. K., \& Eggleton, I. (2003). The decision-facilitating role of management accounting systems on managerial performance: The influence of locus of control and task uncertainty. Advances in Accounting, 20, 165-197.

Chong, V. K., \& Rundus, M. J. (2004). Total quality management, market competition and organizational performance. The British Accounting Review, 36(2), 155-172.

Chow-Chua, C., Goh, M., \& Wan, T. B. (2003). Does ISO9000 certification improve business performance? International Journal of Quality and Reliability Management, 20(8), 936-953.

Claver, E., Tarí, J. J., \& Pereira, J. (2006). Does quality impact on hotel performance. International Journal of Contemporary Hospitality Management, 18(4), 350358.

Claver-Cortés, E., Pereira-Moliner, J., Tarí, J. J., \& MolinaAzoín. J. F. (2008). TQM, managerial factors and performance in the Spanish hotel industry. Industrial Management and Data Systems, 108(2), 228-244.

Covin, J. (1991). Entrepreneurial vs. conservative firms: A comparison of strategies and performance. Journal of Management Studies, 28(5), 439-462.

Curkovic, S., Melnyk, S., Calantone, R., \& Handfield, R. (2000). Validating the Malcolm Baldrige National Quality Award framework through structural equation modeling. International Journal of Production Research, 38(4), 765-791.

Das, A., Handfield, R. B., Calantone, R. J., \& Ghosh, S. (2000). A contingent view of quality management: The impact of international competition on quality. Decision Sciences, 31(3), 649-690.

Day, G. S. (1994). The capabilities of market-driven organizations. Journal of Marketing, 58(4), 37-52.

Dess, G., \& Robinson, R. (1984). Measuring organizational performance in the absence of objective measures: The case of privately-held firm and conglomerate business unit. Strategic Management Journal, 5(3), 265-273.

Douglas, T., \& Judge, W. (2001). Total quality management implementation and competitive advantage: The role of structural control and exploration. Academy of Management Journal, 44(1), 158-169.

Easton, G., \& Jarrell, S. (1998). The effects of total quality management on corporate performance: An empirical investigation. Journal of Business, 71(2), 253-307.

Ekinci, Y. (2008). Service quality and hospitality organizations. In B. Brotherton \& R. C. Wood (Eds.), The SAGE handbook of hospitality management (pp. 316-330). Thousand Oaks, CA: Sage Publications.
Feng, J., Prajogo, D. I., Tan, K. C., \& Sohal, A. S. (2006). The impact of TQM practices on performance. European Journal of Innovation Management, 9(3), 269-278.

Flynn, B. B., \& Saladin B. (2001). Further evidence on the validity of the theoretical models underlying the Baldrige criteria. Journal of Operations Management, 19(6), 617-652.

Flynn, B. B., \& Saladin, B. (2006). Relevance of Baldrige constructs in an international context: A study of national culture. Journal of Operations Management, 24(5), 583-603.

Flynn, B. B., Schroeder, R. G., \& Sakakibara, S. (1994). A framework for quality management research and an associated measurement instrument. Journal of Operations Management, 11(4), 339-366.

Govindarajan, V. (1986). Impact of participation in the budgetary process on managerial attitude and performance: Universalistic and contingency perspectives. Decision Sciences, 17(4), 496-516.

Gul, F. (1991). The effects of management accounting systems and environmental uncertainty on small business managers' performance. Accounting and Business Research, 22(85), 57-61.

Gul, F., \& Chia, Y. (1994). The effect of management accounting systems, perceived environmental uncertainty and decentralization on managerial performance: A test of three way interaction. Accounting, Organizations and Society, 19(4/5), 413-426.

Gul, F., Tsui, J., Fong, S., \& Kwok, H. (1995). Decentralization as a moderating factor in the budgetary participation-performance relationship: Some Hong Kong evidence. Accounting and Business Research, 25(98), 107-113.

Gupta, A., \& Govindarajan, V. (1984). Business unit strategy, managerial characteristics and business unit effectiveness at strategy implementation. Academy of Management Journal, 27(1), 25-41.

Harrington, D., \& Akehurst, G. (1996). Service quality and business performance in the UK hotel industry. International Journal of Hospitality Management, 15(3), 283-298.

Harris, L. C. (2001). Market orientation and performance: Objective and subjective empirical evidence from UK companies. Journal of Management Studies, 38(1), 17-43.

Helgesen, O. (2006). Are loyal customers profitable? Customer satisfaction, customer (action) loyalty and customer profitability at the individual level. Journal of Marketing Management, 22(3), 245-266.

Hendricks, K. B., \& Singhal, V. R. (2001). Firm characteristics, total quality management, and financial performance. Journal of Operations Management, 19(3), 269-285.

Heneman, H. (1974). Comparisons of self and superior ratings of managerial performance. Journal of Applied Psychology, 59(5), 638-642.

Ingram, H., \& Daskalakis, G. (1999). Measuring quality gaps in hotels: The case of Crete. International Journal of Contemporary Hospitality Management, 11(1), 24-30. 
Jogaratanam, G., Tse, E., \& Olsen, M. (1999). Strategic posture, environmental munificence and performance: An empirical study of independent restaurants. Journal of Hospitality and Tourism Research, 23(2), 118-138.

Jun, M., Cai, S., \& Shin, H. (2006). TQM practice in Maquiladora: Antecedents of employee satisfaction and loyalty. Journal of Operations Management, 24, 791812.

Kandampully, J., \& Suhartanto, D. (2000). Customer loyalty in the hotel industry: The role of customer satisfaction and image. International Journal of Contemporary Hospitality Management, 12(6), 346-351.

Kaplan, R. S., \& Norton, D. P. (1992). The balanced scorecard: Measures that drive performance. Harvard Business Review, 70(1), 71-79.

Kaynak, H. (2003). The relationship between total quality management practices and their effects on firm performance. Journal of Operations Management, 21(4), 405-435.

Khandwalla, P. N. (1972). The effects of different types of competition on the use of management control. Journal of Accounting Research, 10(2), 275-285.

Kleinbaum, D. G., Kupper, L. L., \& Muller, K. E. (2008). Applied regression analysis and other multivariable methods (4th ed.). Belmont, CA: Thomson Brooks/Cole.

Knox, A. (2007). Never the twain shall meet? The customeroriented bureaucracy and equal employment opportunity in service work. Management Research News, 30(3), 216-227.

Kuo, T., Chang, T-J., Hung, K-C., \& Lin, M-Y. (2009). Employees' perspective on the effectiveness of ISO 9000 certification: A total quality management framework. Total Quality Management, 20(12), 1321-1355.

Leiper, N. (2003). Tourism management. Sydney: Pearson Sprint Print.

Lim, P. C., \& Tang, N. K. H. (2000). The development of a model for total quality healthcare. Managing Service Quality, 10(2), 103-111.

Mia, L., \& Clarke, B. (1999). Market competition, management accounting systems and business unit performance. Management Accounting Research, 10(2), 137-158.

Nabitz, U., Klazinga, N., \& Walburg, J. (2000). The EFQM excellence model: European and Dutch experiences with the EFQM approach in health care. International Journal for Quality in Health Care, 12(3), 191-201.

Nair, A. (2006). Meta-analysis of the relationship between quality management practices and firm performance: Implications for quality management theory development. Journal of Operations Management, 24(6), 948975.

Nield, K., \& Kozak, M. (1999). Quality certification in the hospitality industry. Cornell Hotel and Restaurant Administration Quarterly, 40(2), 40-45.

Nilsson, L., Johnson, M., \& Gustafsson, A. (2001). The impact of quality practices on customer satisfaction and business results: Product versus service organizations. Journal of Quality Management, 6, 5-27.
Nunnally, J. (1978). Psychometric theory. New York: McGraw-Hill.

Oppenheim, A. (1996). Questionnaire design and attitude measurement. New York: Basic Books.

Parasuraman, A., Zeithaml, A. V., \& Berry, L. L. (1985). A conceptual model of service quality and its implications for future research. Journal of Marketing, 49(4), 41-50.

Patiar, A., \& Mia, L. (2008a). The interactive effect of market competition and use of MAS information on performance: Evidence from the upscale hotels. Journal of Hospitality and Tourism Research, 32(2), 209-234.

Patiar, A., \& Mia, L. (2008b). The effect of subordinates' gender on the difference between self-ratings and superiors' ratings of subordinates' performance in hotels. International Journal of Hospitality Management, 27(1), 53-64.

Patiar, A., \& Mia, L. (2009). Transformational leadership style, market competition and departmental performance: Evidence from luxury hotels in Australia. International Journal of Hospitality Management, 28(2), 254-262.

Powell, T. C. (1995). Total quality management as competitive advantage: A review and empirical study. Strategic Management Journal, 16(1), 15-37.

Rao, A., Carr, L. P., Dambolena, I., Kopp, R. J., Martin, J., Rafii, F., \& Schlesinger, P. F. (1996). Total quality management: A cross functional perspective. New York: John Wiley and Sons.

Reichheld, F. F., \& Sasser Jr, W. E. (1990). Zero defections: Quality comes to services. Harvard Business Review, 68(5), 105-111.

Rust, R. T., Zahorik, A. J., \& Keiningham, T. L. (1995). Return on quality (ROQ): Making service quality financially accountable. Journal of Marketing, 59(2), 58-70.

Santos-Vijande, M. L., \& Álvarez-González, L. I. (2007). Innovativeness and organizational innovation in total quality oriented firms: The moderating role of market turbulence. Technovation, 27(9), 514-532.

Saraph, J. V., Benson, P. G., \& Schroeder, R. G. (1989). An instrument for measuring the critical factors of quality management. Decision Science, 20(4), 810-829.

Schonberger, R. J. (1992). Total quality management cuts a broad swath: Through manufacturing and beyond. Organizational Dynamics, 20(4), 16-28.

Schoonhoven, C. (1981). Problems with contingency theory: Testing assumptions hidden within the language of contingency theory. Administrative Science Quarterly, 26, 349-377.

Sila, I. (2007). Examining the effects of contextual factors on TQM and performance through the lens of organizational theories: An empirical study. Journal of Operations Management, 25(1), 83-109.

Sila, I., \& Ebrahimpour, M. (2002). An investigation of the total quality management survey based research published between 1989 and 2000. International Journal of Quality and Reliability Management, 19(7), 902-970.

Simons, R. (1990). The role of management control systems 
in creative competitive advantage: New perspectives. Accounting, Organizations and Society, 15, 127-143.

Sit, W-Y., Ooi, K-B., Lin, B., \& Chong, A. Y-L. (2009). TQM and customer satisfaction in Malaysia's service sector. Industrial Management and Data Systems, 109(7), 957-975.

Southwood, K. (1978). Substantive theory and statistical interaction: Five models. American Journal of Sociology, 83(5), 1154-1203.

Tabachnick, B. G., \& Fidell, L. S. (2007). Using multivariate statistics (5th ed.). Boston: Pearson Education.

Tarí, J. J., Claver-Cortés, E., Pereira-Moliner, J., \& MolinaAzoín. J. F. (2010). Levels of quality and environmental management in the hotel industry: Their joint influence on firm performance. International Journal Hospitality Management, 29(3), 500-510.

Tata, J., Prasad, S., \& Thorn, R. (1999). The influence of organizational structure on the effectiveness of TQM programs. Journal of Managerial Issues, 11(4), 440453.

Tribe, J. (2005). The economics of recreation, leisure and tourism (3rd ed.). Oxford: Elsevier.

Tsui, J. (2001). The impact of culture on the relationship between budgetary participation, management accounting systems, and managerial performance: An analysis of Chinese and Western managers. The International Journal of Accounting, 36(2), 125-146.

Venkatraman, N., \& Ramnujam, V. (1987). Measurement of business economic performance: An examination of method convergence. Journal of Management,13(1), 109-122.

Walker, J. R., \& Salameh, T. T. (1990). The Q. A. payoff.
Cornell Hotel and Restaurant Administration Quarterly, 30(4), 57-59.

Wallace, R., \& Mellor, C. (1988). Nonresponse bias in mail accounting surveys: A pedagogical note. British Accounting Review, 20(2), 131-139.

Wilkins, H., Merrilees, B., \& Herington, C. (2007). Towards an understanding of total service quality in hotels. International Journal of Hospitality Management, 26(4), 840-853.

Wilson, D. D., \& Collier, D. A. (2000). An empirical investigation of the Malcolm Baldrige National Quality Award causal model. Decision Sciences, 31(2), 361390.

Wylie, K. (2009). Total quality management: A case study of quality award winning organization. Retrieved December 22, 2009, from http://books.google.com/books ?id=Anrv5QMiQAoC\&dq=Riz+calton+total+quality+ management\&lr=lang_en\&source $=$ gbs_navlinks_s

$\mathrm{Yu}, \mathrm{L}$. (2008). The structure and nature of the international hospitality industry. In B. Brotherton \& R. C. Wood (Eds.), The SAGE handbook of hospitality management (pp. 62-89). Thousand Oaks, CA: Sage Publications.

Zeithaml, V. A. (2000). Service quality, profitability, and the economic worth of customers: What we know and what we need to learn. Academy of Marketing Science, 28(1), 67-85.

Zeithaml, V. A., Berry, L. L., \& Parasuraman, A. (1996). The behavioral consequences of service quality. The Journal of Marketing, 60(2), 31-46.

Zeithaml, V. A., Parasuraman, A., \& Berry, L. L. (1990). Delivering quality service. New York: The Free Press. 